Iraqi National Journal of Earth Sciences, Vol. 19, No.2, pp. 11-25, 2019

\title{
Inferred Inversely Reactivated Listric Fault at Chia Gara Anticline, Northern Iraq
}

\author{
Ibrahim S. Ibrahim Aljumaily \\ Department of Geology \\ College of Science \\ Mosul University
}

\author{
Nazar Mohammed Rashid Abdullah \\ Dept. of Applied Geology \\ College of Science \\ Dohuk University
}

(Received 17/6/2019 , Accepted 28/11/2019)

\begin{abstract}
Chia Gara anticline is an E-W extending doubly plunged fold, parallel to the Taurus Mountains having about (80) km length and (12) km width. It is located within the high folded zone of northern Iraq. The exposed rocks range in age from Late Triassic to Late Miocene. Structural analysis of the anticline performed through three traverses transverse to the general fold trend from western plunge zone towards east. Geometrical analysis of fold elements shows that Chia Gara anticline is asymmetrical verging towards north in both first and third traverses, whereas it is more or less symmetrical in the second traverse. Meanwhile, results of Fourier analysis demonstrates that the fold form is more developed in the northern limb of the anticline than in its southern limb, in the first and third traverses. Nevertheless, in the second traverse, the fold form seems more developed in the southern limb compared with the northern limb. The northern vergence of the anticline and its advance development in northern limb in the first and third traverses may reflect the impact of a suture vergent reversely slipped listric fault beneath the anticline sectors in these traverses. However, the obscure of such listric fault in the second traverse may be due to the effect of a sinistral (BF1) and a dextral (BF2) subsurface strike-slip faults transverse to the trend of Chia Gara anticline on either side of the second traverse. The surface expressions of them, as well as others like Zewa and Deralok faults (dextral) are evident in satellite image of the area. The southward pushing of the wedge between (BF1) and (BF2) had opposed the northward reverse displacement of the proposed listric fault beneath the second traverse. The effects of these strike-slip faults (BF1) and (BF2) are evident also in anticlockwise deflection of both axial plane and fold axis attitudes from first to the second traverse, and vice versa from second to the third traverse.
\end{abstract}

Keywords: Chia Gara, listric, strike slip, Taurus, Iraq.

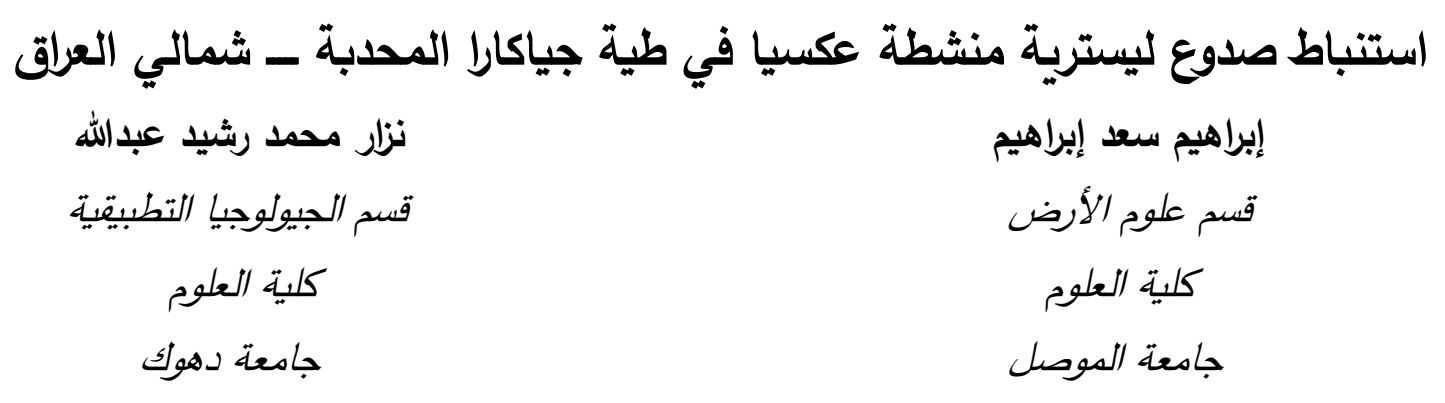




\begin{abstract}
الملخص
تمتد طية جياكارا المحدبة شرق- غرب بطول 80 كم وعرض 12 كم بموازاة سلسلة طوروس وضمن نطاق الطيات العالية شمال العراق. يتراوح عمر صخورها المنكثفة من الترياسي المتأخر إلى المايوسين المتأخر . أجري التحليل التركيبي للطية من خلال ثلاث مسارات مستعرضة للاتجاه العام للطية من غاطسها الغربي ونحو الشرق. أظهر التحليل الهندسي أن الطية غير متتاظرة نحو الثمال في المسارين الأول والثالث ومتتاظرة في المسار الثاني. وبين تحليل فورير أن شكل الطية في الجناح الثمالي أكثر تطورا من الجناح الجنوبي في المسارين الأول والثالث، غير أن شكلها في المسار الثاني يبدو أكثر تطورا في الجناح الجنوبي عما في الجناح الثمالي. إن إتكاء الطية شمالا وتقدم تطورها في الجناح الثمالي في المسارين الأول والثالث قد يعكس تأثير صدع ليستري عكسي الانزلاق ودرزي الاتكاء تحت" قطاعي الطية في هذين المسارين، وإن اختفاء تأثير هذا الصدع في المسار الثاني قد يعود إلى تأثير الصدعين التحت سطحيين والمضربيي الازاحة والمستعرضين على الإي اتجاه الطية، وهما اليسارية (BF1) و اليمينية (BF2) وعلى جانبي المسار الثاني. المظهر السطحي لهذين الصدعين وكذلك لصدعي زيوه وديره لوك اليمينيين واضح في المشهد الفضائي للمنطقة. إن اندفاع الإسفين بين الصدعين (BF1) و (BF2) نحو الجنوب واضح أيضا في الانحراف بعكس اتجاه عقرب الساعة لوضعية المستوى المحوري ومحور الطية من المسار الأول الى المسار الثاني، وبالعكس من المسار الثاني الى الثالث.

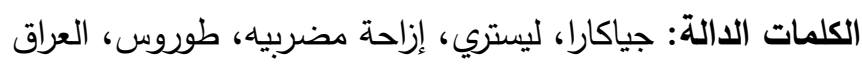

\title{
INTRODUCTION
}

The investigated area is a part of the High Folded Zone of the Western Fold/Thrust Belt in northern Iraq territory (Fouad, 2012) (Figure 1). This belt has been formed as a result of accumulated compressive plate tectonic activities between Arabian and Eurasian plates. Such tectonic compression started with convergence between these plates when the leading oceanic slab of Arabia subducted under Eurasia at Early to Late Jurassic (Sharland et al., 2001), and a slice of southern new Tethys obducted over the Arabian northeastern continental passive margin at late Cretaceous (Numan, 2000; Sharland et al., 2001; Mohajjel et al., 2003; Ali, 2012; Ali et al., 2012). This led to the subsidence of the area to the southwest of the obducted ophiolite belt and hence the initiation of a foreland basin above the Arabian passive margin. Eventually, the compressional convergence was accomplished through the oblique continental collision between Arabia and Eurasia in Middle-Late Miocene (Alavi, 2004 and 2007; Aswad, 1999; Aswad et al., 2011; Agard, 2005 and 2011; Ali et al., 2013). The collision produced Taurus-Zagros orogeny belt which involved intensive folding and thrusting accompanied by emplacement of later ophiolite slivers in the suture zone of the collided plates. The compressional stresses that released from the aforementioned collision have contributed in the folding of the lithostratigraphic sequences of the northern Iraq foreland basin. Such folding was accommodated through inversion of listric faults in the foreland which were inherited from extension period (Triassic) (Numan, 1997; 2000; 2001a and b; Numan and Al-Azzawi, 1993).

The High Fold Zone of northern Iraq is characterized by en-echelon arranged; double plunged, high amplitude and E-W (Taurus) and NW-SE (Zagros) trending 
anticlines. Cretaceous or pre Cretaceous rocks are exposed in the cores of the most of these anticlines. Furthermore, the asymmetries of these folds are either towards north and northeast (Suture-vergent) or towards south and southwest (Foreland-vergent). The variance of vergence directions of these folds reflects the variegated vergence orientations of inversely reactivated listric faults underneath such folds (Numan, 1997; Numan and Al-Azzawi, 1993). However, the intensity of these folds generally decreases towards south and southwest where Low Folded Zone approached.

Chia Gara anticline is one of northern Iraq high folds, extending WNW-ESE for about $80 \mathrm{Km}$. and with an average width of $12 \mathrm{Km}$. (Figure 1b). It is double plunging asymmetrical fold with a steep northern limb (somewhere overturned) and gentle southern limb. The exposed stratigraphic sequence of the anticline extends from Late Triassic until the Late Miocene (Bellen et al.,1959; Jassim and Goff, 2006) (Figure 1b). The oldest is Kurra Chine Formation, which consists of an alternation of thick and thin dolomitic limestone with papery shale and recrystallized breccia fragments and evaporates. This is overlain by early Jurassic Baluti Formation, consisting of grayish green shale with oolitic limestone beds, dolomitic limestone and recrystallized breccia fragments. The overlying unit is Early-Middle Jurassic Serki Formation, which is dolomitic, chalky limestone interbedded with chalky shale, occasionally black dolomitic limestone alternating with shale and marl. This is followed successively upward by Middle Jurassic Sehkaniyan Formation (black, bituminous dolomitic limestone interbedded with organic limestone), Late Jurassic Naokelekan Formation (Lower: bituminous limestone interbedded with bituminous shale. Middle: dolomitic limestone. Upper: limestone, thin bituminous dolomite and black shale beds), late Jurassic Barsarin Formation (limestone, dolomitic limestone, shale and clayey beds), Late Jurassic Chia Gara Formation (thin beds of limestone and calcareous shale). The exposed succession is continued with five Cretaceous formations. They are started with Late Jurassic-Early Cretaceous Garagu Formation (oolitic, sandy limestone at lower and upper parts and detrital organic limestone at middle part), and followed by Early Cretaceous Sarmord Formation (bluish, brown marl interbedded with argillaceous limestone); Middle Cretaceous Qamchuqa Formation (massive dolomitic limestone); Late Cretaceous Bekhme Formation (cavernous reefal, dolomitic limestone with Rudist and basal conglomerate at lower part); Late Cretaceous Shiranish Formation (argillaceous limestone and bluish marl). The sequence is overlain successively by Paleocene Kolosh Formation (grayish green clay, marl, silt and sandstone); Middle Eocene Gercus Formation (red shale, marl, pebbly sandstone and conglomerate); Middle-Late Eocene Pila Spi Formation (lower part: massive limestone-dolomitic beds, upper part: moderately bedded chalky limestone); Middle Miocene Fatha Formation (alteration of marl, shale, clay and marly limestone beds, $2 \mathrm{~m}$ basal conglomerate at base); Late Miocene Injana Formation (alternation of clay and sandstone beds with cross bedding).

The aim of the present work is to elucidate the structural style of Chia-Gara anticline, to correlate the style laterally along the fold extension and transversely across the fold hinge. This is to check whether the fold has been formed passively or accommodated by faults. Then to estimate the local shortening percent that the fold has achieved throughout its development, and the depth to the possible detachment beneath the anticline. 


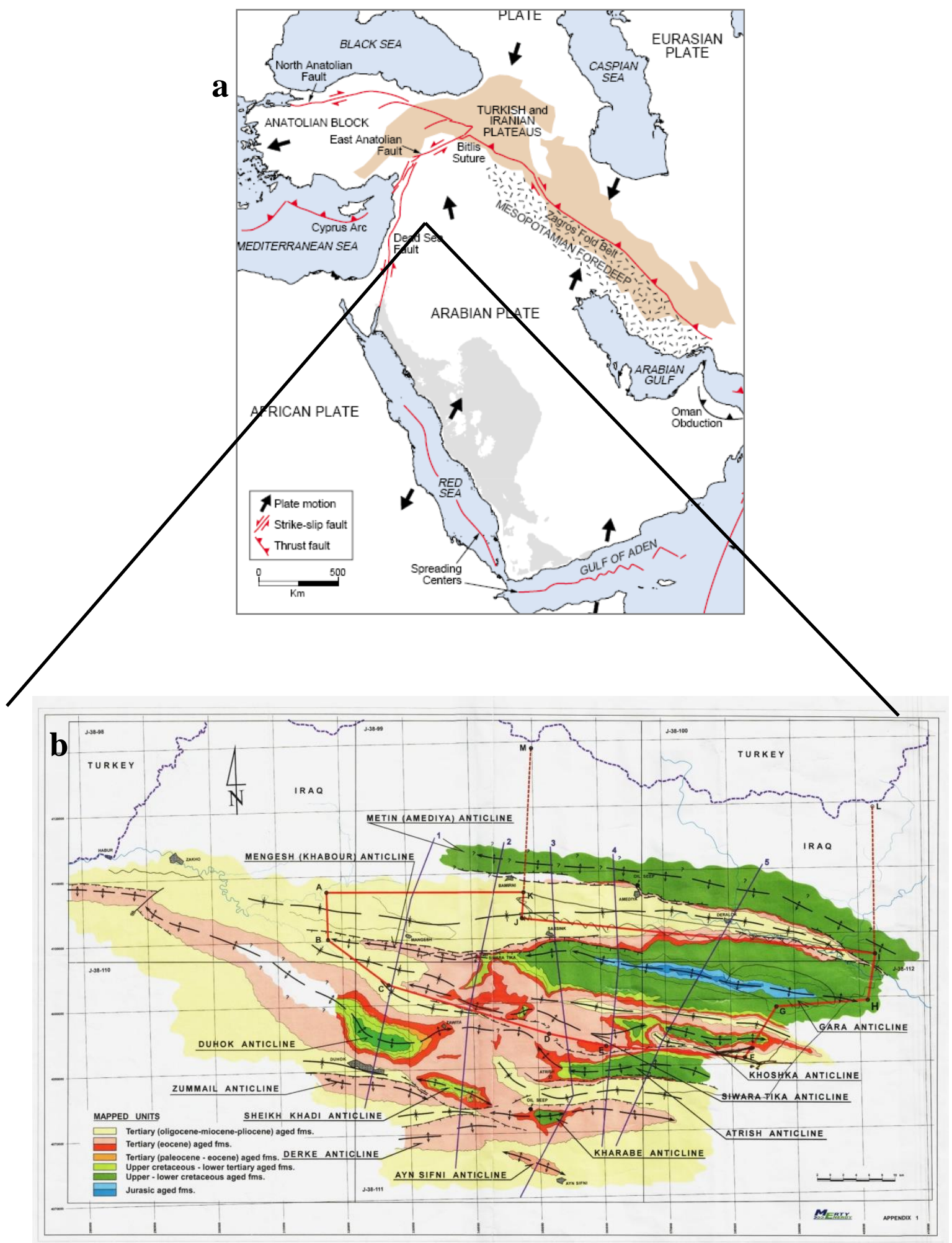

Fig. 1.a: Middle East tectonic setting (Seber et al., 2000). b: Geologic map of Chia Gara and surrounding anticlines (Merty Energy, 2004).

\section{METHODOLOGY}

The gathered field data and measurements are analyzed throughout the following approaches:

1. Stereographic representation of measured bedding attitudes (as PI- diagrams of bedding poles) to determine the geometrical elements such as (fold axis, fold axial 
plane and interlimb angle) and geometrical classification of Chia Gara anticline. The used classifications are of: Fleuty (1964) based on attitude of fold axis and axial plane and the amount of interlimb angle; Rickard (1971) which is based on pitch of fold axis within axial plane and attitude of fold axis and axial plane as well; Ramsay and Huber (1987) according to cylindricity of the fold.

2. Fourier analysis to establish the folded shape of anticline by constructing structural profiles for Chia Gara anticline using Busk method (Busk, 1929). This is a wellknown graphics technique for profile construction of parallel (concentric folds).

Fourier technique is based on the quarter wavelength of fold profile; each quarter of the profile represents a fold limb, through bisecting fold interlimb angle formed by asymptotes on limbs of the profile. The axes of coordinate are rotated until its ordinate becomes parallel to the interlimb angle bisector of the fold. After rotation, the base of the apparent quarter wavelength (AQW) is divided into three equal sectors by perpendiculars parallel to interlimb angle bisector of the profile. The measured lengths of these perpendiculars $\left(\mathrm{y}_{1}, \mathrm{y}_{2}, \mathrm{y}_{3}\right)$ are transformed into standard Stabler values (Stabler, 1968 in Ramsay and Huber, 1987) using the equation:

$\mathrm{Yi}=(\mathrm{yi} * \Pi) /(2 * \mathrm{AQW})$

Then Fourier parameters $\left(b_{1}, b_{3}, b_{5}\right)$ are computed from standard Stabler values using $\mathrm{b} 1=(\mathrm{Y} 1+\sqrt{3} \mathrm{Y} 2+\mathrm{Y} 3) / 3$

$\mathrm{b} 3=(2 \mathrm{Y} 1-\mathrm{Y} 3) / 3$

$\mathrm{b} 5=(\mathrm{Y} 1-\sqrt{3} \mathrm{Y} 2+\mathrm{Y} 3) / 3$

The parameters b1 and b3 have a great effect on the overview of fold amplitude, where $b_{3}$ positive value reduces the significance of $b_{1}$ value on fold shape development, and hence widening its hinge zone. Thus the fold tends to be box shaped. Whereas the negative value of $b_{3}$ tightens fold hinge zone and increases straightness of fold limbs. Thus the fold tends to be chevron (Ramsay and Huber, 1987).

The fold shape classification chart (Hudleston, 1973a), uses $b_{1}$ and $b_{3}$ parameters and excludes $b_{5}$ value for its little effect on fold shape variation where $b_{1}$ plotted as $x-$ axis and $b_{3}$ as $y$-axis, and the fold shapes are nominated according to the ratio $\left(b_{3} / b_{1}\right)$. The following rational values $(-0.111,0.000,0.037,0.165,0.333)$ refer to the following fold shapes respectively (chevron, sinusoidal, parabolic, semielliptical, box). Al-Azzawi (2003) applied Fourier technique comprehensively on foreland folds of northern Iraq and introduced a classification scheme of such folds according to their development.

3. Calculation of the detachment depth and shortening percentage of the anticline. The estimation of local shortening percentage and depth of detachment in the study area are performed using the approach developed by Al-Azzawi (2008) which is principally based on Billings (1972).

The determination of shortening amount of any fold depends on the total rock mass that was uplifted (in anticline) or subsided (in syncline) during folding. The principles and parameters of the technique were derived from Ramsay (1967), Suppe (1985) and Ramsay and Huber (1987), and illustrated in the sketch diagram given by 
Al-Azzawi (2008) (Fig. 2a). In this diagram: $A F$ is the pre-folding cross sectional area of rock mass which is bounded horizontally between $L i$ and $R i$ exposure points of the measurement datum, and vertically between this datum and the supposed detachment horizon. $A B$ is the bulk post-folding cross sectional area and $A R$ is the area of the uplifted rock mass. Then the shortening amount for this fold can be computed as follows:

Shortening $=(L c-L o) / L o$

(5) Ramsay (1967)

Where $L c$ is the post-folding length of conserved bed and $L o$ is its original length.

Shortening percentage $=A R * 100 / A F$...(6)

$S c=L c-L o$

(7) Suppe (1985)

Where $S c$ is curvimetric shortening.

$A s r=S c * h$

(8) Suppe (1985) and Ramsay and Huber (1987)

Where Asr is the area of structural relief which represents uplifted rock mass above the datum joining the exposure points ( $L i$ and $\mathrm{Ri}$ ), and $h$ is the depth to the detachment surface.

Al-Azzawi (2008) introduced another factor named additional tectonic uplift which raised the measurement datum from its original stratigraphic setting and produced additional uplifted area termed $T a$ (Fig. 2b). Thus, the area $A R$ will comprise both areas $A s r$ and $T a$.

In the present investigation, the upper surface of Injana Formation (Late Miocene) is taken as measurement datum because it has been completely deposited before the paroxysmal stage of folding in the foreland belt of Iraq in Pliocene (Jassim and Goff, 2006). Furthermore, the top surface of this formation can be considered as equivalent to sea level at that time since it was deposited in a fluvial environment (Jassim and Goff, 2006). And since there is no eustatic difference between the Late Miocene sea level and that of the present day (Sharland et al., 2001). The additional tectonic uplift can be equivalent to the present-day elevation of the top of Injana Formation, here assigned Injana Elevation (Ie) (Fig. 2b). Thus:

$T a=L o * I e$

Where $T a$ is the area resulted due to additional tectonic uplift, and it must be added to the area of the uplifted mass $A R$.

$A R=A s r+T a$

Consequently, the shortening percentage of any given fold will be:

Shortening $\%=(A s r+T a) * 100 / A F$ 

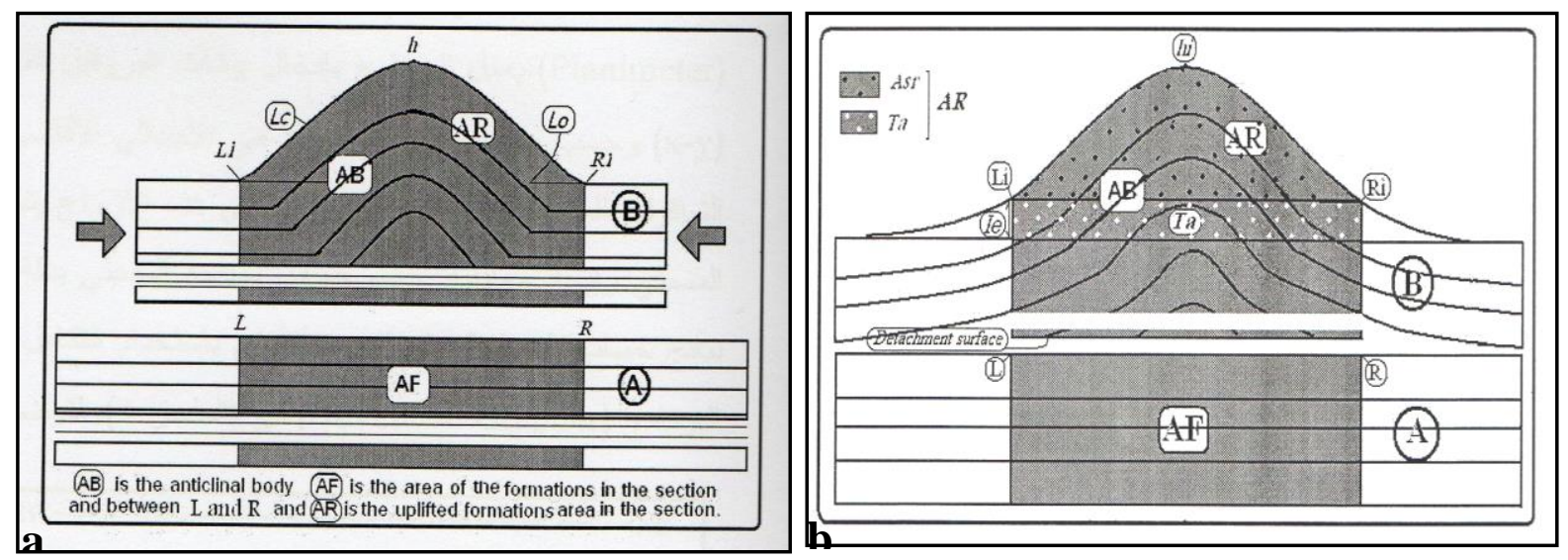

Fig. 2: Sketch diagrams illustrating geometrical parameters of local shortening computation (Al-Azzawi, 2008). a: before tectonic uplift, b: effect of tectonic uplift after shortening. Symbols are explained in the text.

\section{STEREOGRAPHIC ANALYSIS (PI-DIAGRAMS)}

Figures (3A, B, C) and tables (1and 2) illustrate the results of this mode of analysis and the geometrical classifications of the anticline at the three traverses. Comparison of these results shows some differences. The interlimb angle of the fold in the second traverse is larger than that in the first and third traverses (Table 1). There are also noticeable differences in attitudes of both the fold axis and the axial plane among the three traverses (Table 1). For instance, the attitudes of fold axis and axial plane in the first traverse (261/04 and 263/78 respectively) are varying counter clockwise to (252/06 and 250/84 respectively) in the second traverse, their variances in orientation are $\left(9^{\circ}\right.$ and $\left.13^{\circ}\right)$ respectively. Whereas the variance is clockwise in the third traverse (267/06 and 268/74 respectively), that is the variance in orientations of fold axis and axial plane amounts to $\left(15^{\circ}\right.$ and $\left.18^{\circ}\right)$ respectively. The fold is asymmetrical towards north in the first and third traverses. Whereas it approaches symmetry in the second traverse. Thus, the anticline is suture vergent (toward north) along the first and third traverses.
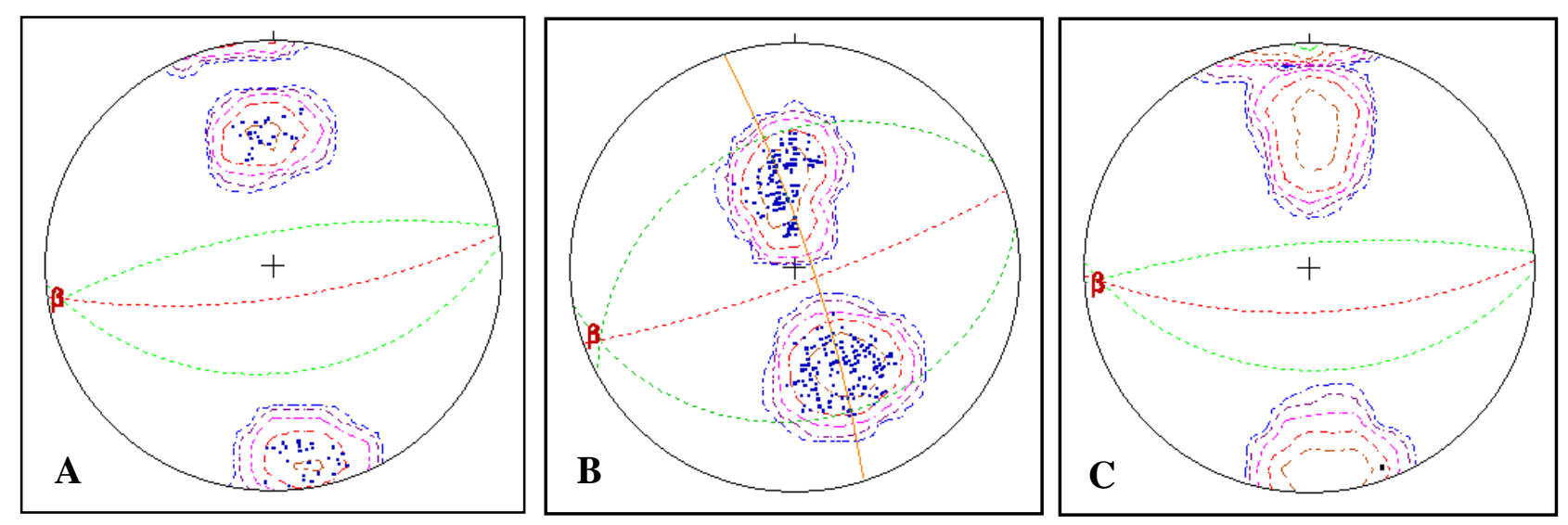

Fig. 3: Stereographic PI diagrams of Chia Gara anticline, A- First traverse, B- Second traverse, C- Third traverse 
Table 1: Geometrical fold parameters of Chia Gara anticline.

\begin{tabular}{|c|c|c|c|c|c|c|c|}
\hline \multirow[b]{2}{*}{ Traverse } & \multicolumn{4}{|c|}{ Attitude } & \multirow{2}{*}{$\begin{array}{l}\text { Interlimb } \\
\text { angle }\end{array}$} & \multirow[b]{2}{*}{ Symmetry } & \multirow[b]{2}{*}{ Vergence } \\
\hline & $\begin{array}{l}\text { Northern } \\
\text { limb }\end{array}$ & $\begin{array}{l}\text { Southern } \\
\operatorname{limb}\end{array}$ & $\begin{array}{l}\text { Fold } \\
\text { axis }\end{array}$ & $\begin{array}{l}\text { Axial } \\
\text { plane }\end{array}$ & & & \\
\hline First & 080/78 & $265 / 50$ & $261 / 04$ & $263 / 78$ & 52 & Asymmetrical & Suture \\
\hline Second & $062 / 41$ & $260 / 32$ & $252 / 06$ & $250 / 84$ & 107 & $\begin{array}{c}\text { Nearly } \\
\text { symmetrical }\end{array}$ & \\
\hline Third & $086 / 81$ & $271 / 52$ & $267 / 06$ & $268 / 74$ & 47 & Asymmetrical & Suture \\
\hline
\end{tabular}

Table 2: Fold geometrical classifications of Chia Gara anticline.

\begin{tabular}{|c|c|c|c|c|}
\hline Traverse & Fleuty $(1964)^{*}$ & Fleuty $(1964)^{* * *}$ & $\begin{array}{l}\text { Rickard } \\
(1971)^{* * * *}\end{array}$ & $\begin{array}{l}\text { Ramsay } \\
(1987)^{* * * * *}\end{array}$ \\
\hline First & Close & $\begin{array}{l}\text { Sub horizontal steep } \\
\text { dip }\end{array}$ & Horizontal & Semi cylindrical \\
\hline Second & Open & Sub horizontal upright & $\begin{array}{c}\text { Horizontal } \\
\text { upright }\end{array}$ & Semi cylindrical \\
\hline Third & Close & $\begin{array}{l}\text { Sub horizontal steep } \\
\text { dip }\end{array}$ & Horizontal & Semi cylindrical \\
\hline
\end{tabular}

* based on Interlimb angle, ** based on the axial plane dip and plunge of fold axis, *** based on the axial plane dip and plunge and pitch of fold axis, $* * * *$ based on cylindricity

Furthermore, PI-diagrams were plotted for Pila Spi Formation alone at the three traverses to compare fold characteristics in this unit with the results of Fourier analysis that was made upon Busk based structural profiles of Chia Gara anticline for the same formation at the three traverses. Figure (4) and tables $(3,4)$ illustrate the fold characteristics in the Pila Spi Formation.
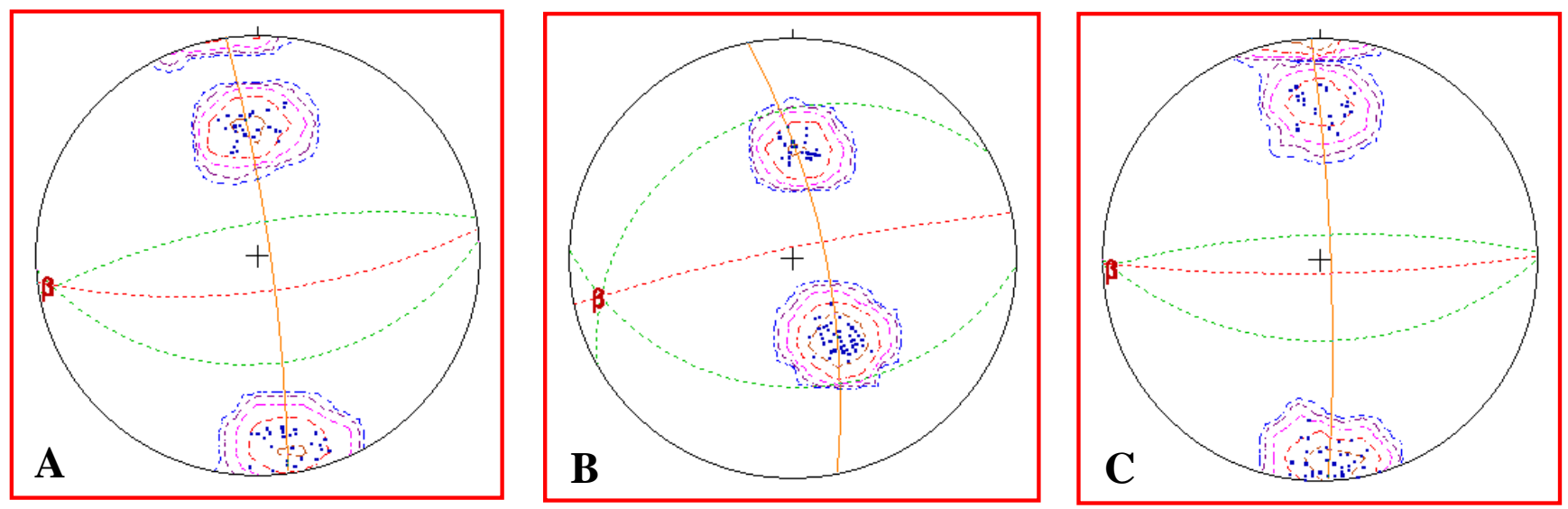

Fig. 4: Stereographic PI diagrams of Pila Spi Formation at Chia Gara anticline, A- First traverse, B- Second traverse, C- Third traverse 
Table 3: Geometrical fold parameters of Chia Gara anticline (Pila Spi Formation).

\begin{tabular}{|c|c|c|c|c|c|c|c|}
\hline \multirow[b]{2}{*}{ Traverse } & \multicolumn{4}{|c|}{ Attitude } & \multirow{2}{*}{$\begin{array}{l}\text { Interlimb } \\
\text { angle }\end{array}$} & \multirow[b]{2}{*}{ Symmetry } & \multirow[b]{2}{*}{ Vergence } \\
\hline & $\begin{array}{l}\text { Northern } \\
\text { limb }\end{array}$ & $\begin{array}{c}\text { Southern } \\
\operatorname{limb}\end{array}$ & $\begin{array}{l}\text { Fold } \\
\text { axis }\end{array}$ & $\begin{array}{l}\text { Axial } \\
\text { plane }\end{array}$ & & & \\
\hline First & $080 / 78$ & $266 / 49$ & $262 / 05$ & $263 / 77$ & 53 & Asymmetrical & Suture \\
\hline Second & $061 / 35$ & $272 / 41$ & $258 / 12$ & $078 / 86$ & 104 & Asymmetrical & Foreland \\
\hline Third & $088 / 81$ & $270 / 60$ & $268 / 04$ & $277 / 85$ & 39 & Asymmetrical & Suture \\
\hline
\end{tabular}

Table 4: Fold geometrical classifications of Chia Gara anticline (Pila Spi Formation).

\begin{tabular}{|c|c|c|c|c|}
\hline Traverse & Fleuty(1964)* & Fleuty (1964) & $\begin{array}{c}\text { Rickard } \\
(\mathbf{1 9 7 1})^{* * * *}\end{array}$ & $\begin{array}{c}\text { Ramsay } \\
(\mathbf{1 9 8 7})^{* * * * *}\end{array}$ \\
\hline First & Close & $\begin{array}{c}\text { Sub horizontal steep } \\
\text { dip }\end{array}$ & Horizontal & Semi cylindrical \\
\hline Second & Open & $\begin{array}{c}\text { Gently plunging } \\
\text { upright }\end{array}$ & upright & Semi cylindrical \\
\hline Third & Close & Sub horizontal upright & $\begin{array}{c}\text { Horizontal } \\
\text { upright }\end{array}$ & Semi cylindrical \\
\hline
\end{tabular}

Star symbols indicating as in table 2.

\section{FOURIER ANALYSIS OF FOLD SHAPE}

Fourier analysis is applied on Busk based structural profiles of Chia Gara anticline (upper surface of PilaSpi formation) at the three traverses. The results of this analysis are illustrated in table (5) below. It is evident that the fold shape of Chia Gara anticline is more progressed along northern limb than along southern limb in the first and third traverses and vice versa in the second traverse. This anomaly might be attributed to the interaction between the suture vergent inversely reactivated listric fault beneath the anticline and the strike slip motion of senistral $\mathrm{BF}_{1}$ and dextral $\mathrm{BF}_{2}$ faults (interpreted from satallite imagery, Doski, 2004) along the second traverse (Fig. 5). The southerly motion of the northern wedge sector in between these faults has reduced the inversely reactivation of the supposed suture vergent listric fault beneath the anticline at the second traverse. Therefore, the southern limb of the anticline stayed more developed than its northern limb at this traverse. 
Table 5: Fourier parameters and fold shape classes of Chia Gara anticline according to Hudleston (1973a).

\begin{tabular}{|c|c|c|c|c|c|c|c|c|c|c|c|c|}
\hline Traverse & $\mathbf{l i m b}$ & $\mathbf{y}_{1}$ & $\mathbf{y} \mathbf{2}$ & $\mathbf{y} \mathbf{3}$ & $\mathbf{A Q W}$ & $\mathbf{Y}_{\mathbf{1}}$ & $\mathbf{Y}_{\mathbf{2}}$ & $\mathbf{Y}_{\mathbf{3}}$ & $\mathbf{b}_{\mathbf{1}}$ & $\mathbf{b}_{\mathbf{3}}$ & $\mathbf{b}_{3} / \mathbf{b}_{1}$ & Fold shape \\
\hline \multirow{2}{*}{ First } & North & 2.9 & 3.9 & 3.4 & 5.7 & 0.799 & 1.074 & 0.936 & 1.186 & 0.22 & 0.185 & $\begin{array}{c}\text { Semielliptical- } \\
\text { Box }\end{array}$ \\
\cline { 2 - 12 } & South & 4.2 & 6.2 & 7.6 & 7.5 & 0.879 & 1.298 & 1.590 & 1.558 & 0.056 & 0.036 & $\begin{array}{c}\text { Sinusoidal- } \\
\text { Parabolic }\end{array}$ \\
\hline \multirow{2}{*}{ Second } & North & 1.6 & 2.7 & 3.1 & 7 & 0.359 & 0.605 & 0.695 & 0.694 & 0.007 & 0.01 & $\begin{array}{c}\text { Sinusoidal- } \\
\text { Parabolic }\end{array}$ \\
\cline { 2 - 12 } & South & 1.5 & 2.2 & 2.5 & 5.8 & 0.406 & 0.595 & 0.677 & 0.698 & 0.045 & 0.064 & $\begin{array}{c}\text { Parabolic- } \\
\text { Semielliptical }\end{array}$ \\
\hline \multirow{2}{*}{ Third } & North & 5.5 & 6.7 & 6.3 & 9.3 & 0.928 & 1.131 & 1.063 & 1.304 & 0.264 & 0.202 & $\begin{array}{c}\text { Semielliptical- } \\
\text { Box }\end{array}$ \\
\cline { 2 - 12 } & South & 6.7 & 9.3 & 10.7 & 10.1 & 1.041 & 1.446 & 1.663 & 1.72 & 0.139 & 0.08 & $\begin{array}{c}\text { Parabolic- } \\
\text { Semielliptical }\end{array}$ \\
\hline
\end{tabular}

Explanation of symbols: $\left(\mathrm{y}_{1}, \mathrm{y}_{2}, \mathrm{y}_{3}\right)$ are lengths in $\mathrm{cm}$. of perpendiculars upon the base of the apparent quarter wavelength of the fold (AQW), AQW is in $\mathrm{cm} .,\left(\mathrm{Y}_{1}, \mathrm{Y}_{2}, \mathrm{Y}_{3}\right)$ are standard Stabler values, $\left(b_{1}, b_{3}\right)$ are Fourier parameters.

\section{SHORTENING PERCENTAGE AND DEPTH OF DETACHMENT BENEATH CHIA GARA ANTICLINE}

In order to calculate the shortening percentage of the anticline and to estimate the underlying detachment depth, both the curved and the straight lengths of the fold profile as well as its area (Asr) were measured at each of the three traverses. Then the other required parameters were computed based on a fore mentioned measurements as demonstrated in the methodology and illustrated in table (6).

The calculations reveal that the anticline has been shortened relatively more along the first traverse than along the other two traverses, meanwhile it has been more shortened along the third traverse as compared with the second traverse. These variances in shortening percentages might be attributed also to the reduction the effect of the inversely reactivation of the suture-vergent listric fault beneath the second traverse as compared with the first and third traverses. This intensity reduction in inversely reactivation of the listric fault beneath the anticline at the second traverse is due to the interplay of BF1 and BF2 strike slip faults during the folding process.

However, calculations reveal gradual increase of detachment beneath Chia Gara anticline from the first to the third traverse; that is from the western plunge of the anticline towards its central sector. This result seems reasonable where folding depth shallows outwards from a central sector. 
Table 6: Local shortening percentages and depth to the detachment at Chia Gara anticline.

\begin{tabular}{|c|c|c|c|c|c|c|c|c|c|c|}
\hline \begin{tabular}{l}
$\overrightarrow{1}$ \\
\multirow{2}{0}{} \\
0 \\
0 \\
0
\end{tabular} & $\mathrm{Lc}$ & Lo & $\begin{array}{c}\mathrm{Sc}=\mathrm{Lc}- \\
\text { Lo }\end{array}$ & Asr & $\mathrm{h}=\mathrm{Asr} / \mathrm{Sc}$ & $\mathrm{AF}=\mathrm{Lo}^{*} \mathrm{~h}$ & Ie & $\mathrm{Ta}=\mathrm{Ie}^{*}$ lo & 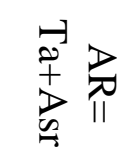 & $\begin{array}{l}(\mathrm{AR} / \mathrm{A} \\
\mathrm{F})^{*} 100\end{array}$ \\
\hline First & 11 & 8.2 & 2.8 & 15.009 & 5.4 & 44.28 & 1.3 & 10.7 & 25.6 & $57.9 \%$ \\
\hline $\begin{array}{c}\text { Seco } \\
\text { nd }\end{array}$ & 8.7 & 7.6 & 1.1 & 8.007 & 7.3 & 55.48 & 1.3 & 9.88 & 17.887 & $32.2 \%$ \\
\hline Third & 14 & 11 & 3 & 28.013 & 9.3 & 102.3 & 1.3 & 14.3 & 42.3 & $41.4 \%$ \\
\hline
\end{tabular}

Explanation of symbols: Lc $=$ curved length of the fold profile, $L o=$ horizontal length of the fold profile, $\mathrm{Sc}=$ length difference between the curved and horizontal lengths of the fold profile, $\mathrm{Asr}=$ area of the fold profile, $\mathrm{h}=$ depth of detachment, $\mathrm{AF}=$ cross sectional area before folding, $\mathrm{Ie}=$ elevation of the Injana Formation top, $\mathrm{Ta}=$ amount of additional tectonic uplift, $\mathrm{AR}=$ total area of tectonic uplift, Shortening percentage $=(\mathrm{AR} / \mathrm{AF})^{*} 100 . \mathrm{Lc}, \mathrm{Lo}, \mathrm{Sc}, \mathrm{h}$ and Ie in $\mathrm{km}$. Asr, AF, Ta and $\mathrm{Ar}$ in $\mathrm{km}^{2}$

\section{DISCUSSION}

Stereographic analysis of bedding attitudes reveals lateral variation in fold parameters of the western part of Chia Gara anticline which in turn reflects the variance in folding intensity (compressive stress intensity) along the fold. For instance, the variance in fold tightness between the second and the other two traverses reflects variance in fold intensity among these traverses. So it is inferred that folding across the second traverse sector was less intensive than sectors of the other traverses. This lateral variance in stress intensity might be related to the effect of transversal strikeslip faults among these traverses during folding (Fig. 5).

The imposed vergence of the anticline must be towards south (Foreland-vergent) in all three traverses because the main compressive stress is from north-northeast (Arabian and Eurasian plates' collision). But the reversal of fold vergence towards north, might attribute to the inverse reactivation of a suture-vergent (north) listric fault beneath the anticline.

However, interpretation of satellite imagery of Chia Gara anticline and surrounding structures in the present as well as in previous investigations have revealed traces of strike-slip faults transverse to these folds (Doski, 20004) (Fig. 5). These faults were denoted BF1 (Sinistral) between second and third traverses, and BF2 (Dextral) between first and second traverses. The impact of relative movement on these faults is evident in the attitude variation of fold elements among these traverses. Moreover, the supposed relative movement of the wedge mass between these strikeslip faults might constrain the inverse reactivation of suture- vergent listric fault in the second traverse as compared with the first and third traverses. This had reduced folding intensity in the second traverse (interlimb angle $107^{\circ}$ ) relative to other traverses (interlimb angles $52^{\circ}$ and $47^{\circ}$ ) (Table 1 ).

Furthermore, Fourier analysis of fold profiles demonstrates the progress of the fold shape of the northern limb of the anticline relative to its southern limb at the first and third traverses. This might reflect the inverse reactivation of suture-vergent listric fault beneath the anticline in these traverses. Whereas under development of fold shape at second traverse as compared with the first and third traverses, might attributed 
to the movement of wedge mass between the sinistral (BF1) and dextral (BF2) strike slip faults in opposite direction to the supposed inverse movement of suture-vergent listric fault beneath the anticline at the second traverse. However, this might lead to the progression of southern limb fold shape relative to the northern limb at this traverse.

The relatively low shortening percentage in the second traverse as compared with the other traverses might be related to the impact of BF1 and BF2 strike-slip faults which reduced folding intensity in the second traverse. However, the gradual depth increase of the detachment towards east (from first to third traverse) is reasonable, that is folding depth shallows towards plunges from a central sector.

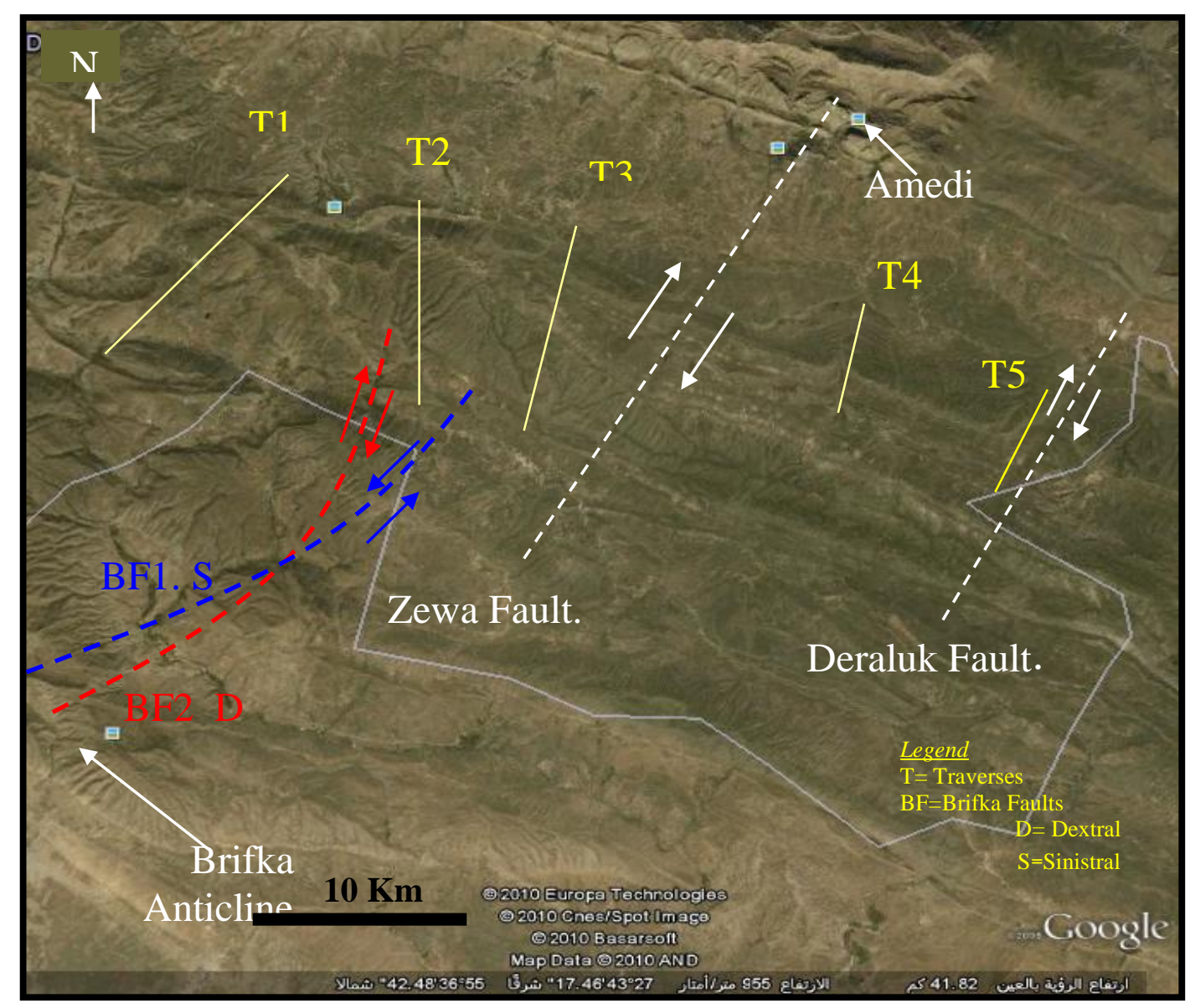

Fig. 5: Traces of transversal strike slip faults across Chia Gara anticline, D: dextral, S: sinistral (Google earth image).

\section{CONCLUSIONS}

A suture-vergent inversely reactivated listric fault is inferred throughout structural and Fourier analysis of fold shape and geometrical elements in the western part of Chia Gara anticline. The axial plane is dipping towards the south in three investigated traverses indicating suture vergence of the anticline, which in turn reflects the probable impact of reverse movement of an already suture-vergent listric fault beneath Chia Gara anticline. This inference is supported by fold progression in the northern limb of the anticline relative to its southern limb according to results of Fourier analysis at the first and third traverses. However, application of the same technique on the second traverse reveals an opposite pattern of fold progression. This 
discrepancy might be attributed to the impact of conjugate strike-slip faults within this traverse.

The estimation of depth to the detachment beneath Chia Gara anticline along the three traverses shows a gradual increase from western plunge area (first traverse) of the anticline towards its central sector. This is compatible with folding process in which fold depth shallows laterally towards plunges. On the other hand, locally shortening percentage computation reveals low shortening in the second traverse relative to the first and third ones. This might be attributed to the reduction of folding intensity within the second traverse due to the effect of transversal strike-slip faults during folding.

The investigation reveals also attitude variations of the fold axis and axial plane counter-clockwise from the first to second traverse and clockwise from the second to third traverse. This lateral variation of fold attitudes might reflects strike-slip faults transverse to the anticline trend. These faults are interpreted from satellite images in the present as well as in previous investigations. These faults are denoted here BF1 sinistral and BF2 dextral faults displaying a conjugate pattern around the second traverse, Zewa and Deraluk dextral faults in between the third, fourth and fifth traverses respectively.

\section{REFERENCES}

Agard, P., J. Omrani, L. Jolivet and F. Mouthereau, 2005. Convergence history across Zagros (Iran): Constraints from collisional and earlier deformation. International Journal of Earth Science, Vol. 94, No. 3, pp. 401-419.

Agard, P., J. Omrani, L. Jolivet, H. White church, B. Vrielynck, W. Spakman, P. Monié, B. Meyer and R. Wortel, 2011. Zagros orogeny: A subduction-dominated process. Geological Magazine, Vol. 148, pp. 692-725.

Alavi, M., 2004. Regional stratigraphy of the Zagros fold thrust belt of Iran and its pro foreland evolution. American Journal of Science, Vol. 304, pp. 1-20.

Alavi, M., 2007.Structures of the Zagros Fold-Thrust Belt in Iran. American Journal of Science, Vol. 307, pp. 1064-1095.

Al-Azzawi, N.K., 2008. Local shortening of folds and detachment surface depth with examples from the foreland belt of Iraq. Iraq Journal of Earth Sciences, Vol. 8, No. 1, pp. 34-43.

Ali S. A., 2012. Geochemistry of Tethyan-arc related volcanic rocks. NE Iraq. PhD thesis, University of Wollongong, $326 \mathrm{p}$ (unpublished).

Ali S. A., Buckman S., Aswad K. J., Jones B. G., Ismail S. A. and Nutman A. P., 2013. The tectonic evolution of a Neo-Tethyan (Eocene-Oligocene) island-arc (Walash and Naopurdan groups) in the Kurdistan region of the Northeast Iraqi Zagros Suture Zone. Island Arc, Vol.22, pp. 104-125. 
Ali S. A., Buckman S., Aswad K. J., Jones B. G., Ismail S. A. and Nutman A. P., 2012. Recognition of Late Cretaceous Hasanbag ophiolite-arc rocks in the Kurdistan region of the Iraqi Zagros Thrust Zone: A missing link in the paleogeography of the closing Neo-Tethys Ocean. Lithosphere, Vol. 4, pp. 395-410. doi:10.1130/L207.1.

Aswad K. J., Aziz N. R. H. and Koyih A., 2011. Cr-spinel compositions in serpentinites and their implications for the petrotectonic history of the Zagros Suture Zone, Kurdistan Region, Iraq. Geological Magazine, Vol. 148, pp. 802-18.

Aswad, K.J., 1999. Arc continent collision in NE. Iraq as evidenced by the Mawat and Penjwin ophiolite complexes. Raf. Jour. Sci., Vol. 10, No.1, pp. 51-61.

Billings, M., 1972. Structural Geology, $3^{\text {rd }}$ Edition, Prentice- Hall Inc.

Doski, J. A. H., 2004. A new contribution to the structural geology of Dohuk area (Kurdistan-Iraq). Journal of Dohuk University, Vol. 7, No. 2, pp. 6-13.

Fleuty, M .J. 1964. The description of folds. Geol. Assoc. London, Proc, Vol. 75, pp. 461-492.

Hudleston, P.J., 1973a. Fold morphology and some geometrical implications of theories of fold development. Tectonophysics, Vol. 16, pp. 1-46.

Jassim, S. Z. and Goff J.C., 2006. Geology of Iraq. Pargue and Musem, Brno Czech Republic.

Mohajjel M., Fergusson C. L. and Sahandi M. R., 2003. Cretaceous-Tertiary convergence and continental collision, Sanandaj-Sirjan Zone, western Iran. Journal of Asian Earth Sciences, Vol. 21, pp. 397-412.

Numan, N.M.S. and Al-Azzawi, N.K., 1993. Structural and geotectonic interpretation of vergence directions of the anticlines in the Foreland Folds of Iraq. Abhath A1Yarmouk (Pure Science and Engineering), Yarmouk University, Jordan, Vol. 2, No. 2.

Numan, N.M.S., 1997. A plate tectonic scenario for the Phanerozoic succession in Iraq. Jour. Geol. Soc. Iraq, Vol. 30, No. 2, pp. 85-110.

Numan, N.M.S., 2000. Major Cretaceous Tectonic Events in Iraq. Raf. Jour. Sci., Vol. 11, No. 3, pp. 32-52.

Numan, N.M.S., 2001a. Cretaceous and Tertiary Alpine subductional history in northern Iraq. Iraqi Jour. Earth Sci., Vol. 1, No. 2, pp.59-74.

Numan, N.M.S., 2001b. Discussion on "Dextral transpression in Late Cretaceous continental collision, Sanandaj-Sirjan zone, western Iran”. J. Struct. Geol., Vol. 23, pp. 2033-2034. 
Ramsay, J. G., 1967. Folding and Fracturing of Rocks, McGraw Hill, New York, 568p.

Ramsey, J.G. and Huber, M.I., 1987. The techniques of modern structural geology. Vol. 2, Folds and fractures, London: Academic press.

Rickard, M.J., 1971. A classification diagram for fold orientation. Geol., Vol. 198, pp. $22-26$.

Seber, D., Steer, D., Sandvol, E., Sandvol, C., Brindisi, C., and Barazangi, M., 2000. Design and development of Information Systems for the Geosciences: An Application to the Middle East, GeoArabia, Vol. 5, No. 2, pp. 269-296.

Sharland, P.R., R. Archer, D.M. Casey, R.B. Davies, S.H. Hall, A.P. Heward, A.D. Horbury and M.D. Simmons, 2001. Arabian Plate sequence stratigraphy, GeoArabia Special Publication Vol. 2, Gulf Petro Link, Bahrain, 371p., with 3 charts.

Suppe, J., 1985. Principles of Structural Geology, Prentice Hall International, Inc., London, 537p.

Van Bellen, R.C., H.V. Dunnington, R. Wetzel and D.M. Morton, 1959-2005. Lexique Stratigraphique International. 0310 Asia, (Iraq), 333p. Reprinted by permission of CNRS by Gulf Petro Link, Bahrain. 